\title{
Helicobacter pylori and gastric cancer
}

\author{
Hidekazu Suzuki, Eisuke Iwasaki, and Toshifumi Hibi \\ Division of Gastroenterology and Hepatology, Department of Internal Medicine, Keio University School of Medicine, 35 Shinanomachi, \\ Shinjuku-ku, Tokyo 160-8582, Japan
}

\begin{abstract}
Helicobacter pylori is now well known as an important pathogen related to the development of gastric cancer. However, some clinicians still doubt the causal association of $\boldsymbol{H}$. pylori with the development of gastric cancer. To summarize the recent clinical data on the link between $H$. pylori and gastric cancer, we reviewed related articles published over the past 3 years, after the award of the Nobel Prize for Physiology or Medicine to Drs. J.R. Warren and B.J. Marshall for the first culture and isolation of $\mathrm{H}$. pylori and the investigation of their relevance to peptic ulcer disease. This updated summary of the relationship between $\boldsymbol{H}$. pylori and gastric cancer highlights the strong link between the organism and the development of gastric cancer, and suggests eradication of this bacterial infection as a possible prophylactic measure against the development of this lethal malignancy. At present, clinicians and researchers in the field emphasize the strong need for $H$. pylori eradication from the human stomach.
\end{abstract}

Key words Gastric cancer · Helicobacter pylori $\cdot$ Eradication · Randomized controlled trial · Gene polymorphism · Food factor

\section{Introduction}

In December 2005, Dr. J.R. Warren and Dr. B.J. Marshall were awarded the Nobel Prize for Physiology or Medicine [1]. At that time, although they received the award for their work on the culture and isolation of Helicobacter pylori and their recognition of the potent etiological relation of this organism to gastritis and peptic ulcer disease [2], the possible relation of $H$. pylori to the development of gastric cancer had not yet been fully evaluated $[1,3]$. However, in the period before their Nobel Prize award in 2005, outstanding findings about the relationship between $H$. pylori and gastric

Offprint requests to: $\mathrm{H}$. Suzuki

Received: February 2, 2009 / Accepted: March 25, 2009 cancer had been reported. In 1994, the International Agency for Research on Cancer and the World Health Organization (WHO) classified H. pylori as a definite (group I) carcinogen [4], based upon epidemiological data using serum anti-H. pylori IgG [5-7]. Subsequently, large-scale prospective clinical studies clearly showed the causal relationship between $H$. pylori and gastric cancer development [8-11]. Uemura et al. [8] prospectively studied $1526 \mathrm{H}$. pylori-positive and $280 \mathrm{H}$. pylorinegative subjects for an average of 7.8 years and showed that gastric cancers developed in $36(2.4 \%)$ of the infected and none of the uninfected patients. On the other hand, a large-scale randomized prospective comparative study in China, carried out by Wong et al. [10], investigating $1630 \mathrm{H}$. pylori-positive subjects (817 receiving and 813 not receiving $H$. pylori eradication) for 7 years showed no significant difference in gastric cancer development between the two treatment arms $(P=0.33)$ [10]. However, because their definition of preneoplastic lesions included so-called "early gastric cancer" in the category of dysplasia, Wong et al. [10] counted only advanced gastric cancer cases as the gastric cancer group, suggesting a difficulty in making direct comparisons with other studies. According to a metaanalysis by Huang et al. [12], H. pylori infection was associated with gastric cancer, but there was little information on early gastric cancer at that time. In terms of the recurrence of early gastric cancer after endoscopic mucosal resection, Uemura et al. [13], in 1997, showed significantly less frequent recurrence in patients with $H$. pylori eradication. In the present article we review the clinical data confirming the link between $H$. pylori infection and gastric cancer published after the award of the Nobel Prize mentioned above (2006-2008).

\section{Methods employed for literature review (Fig. 1)}

A literature search was performed in PubMed using the key words [Helicobacter pylori] and [gastric cancer] 


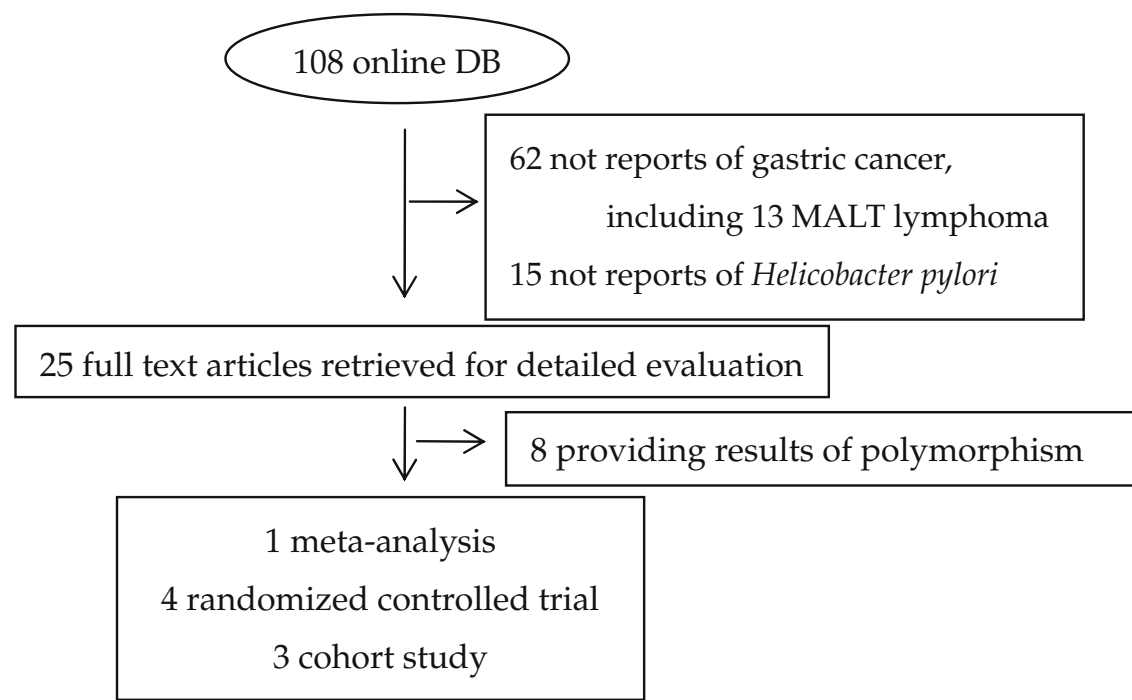

Fig. 1. Literature selection flow. $D B$, database; MALT, mucosa-associated lymphoid tissue and the list was limited to studies added to PubMed or published over the past 3 years (2006-2008), to human studies, meta-analyses, practice guidelines, randomized controlled trials, clinical trials (phase I, II, III, IV), comparative studies, systematic reviews, and to studies including subjects older than 19 years. After compiling a list of the 108 studies included, 83 publications not directly involving the link between $H$. pylori and the development of gastric cancer were excluded. The remaining 25 studies were finally systematically reviewed.

\section{Results of the literature review (Fig. 1)}

Of the 25 clinical studies dealing with the relationship between $H$. pylori infection and the development of gastric cancer, 4 were randomized controlled trials (RCTs) [14-17], 1 was a meta-analysis [18], 3 were cohort studies [19-21], 9 were case-control studies [2230 ], and 8 examined gene polymorphisms related to the link between $H$. pylori and gastric cancer [26, 31-37]. Two European studies [38, 39] showed a relationship between dietary factors and $H$. pylori-associated gastric cancer development.

\section{Randomized controlled trials (RCTs; Table 1)}

You et al. [14] conducted an RCT to examine the effects of one-time $H$. pylori treatment and long-term intake of vitamin or garlic supplements in reducing the prevalence of advanced precancerous gastric lesions. In their study, most of the adults (age, 35-64 years) in 13 randomly selected villages underwent baseline endoscopies in 1994. Then, in 1995, 3365 eligible subjects were randomly assigned to one of three interventions or a placebo group: amoxicillin + omeprazole for 2 weeks in
1995; vitamin C, vitamin E, and selenium for 7.3 years; aged garlic extract and steam-distilled garlic oil for 7.3 years. The $H$. pylori eradication treatment resulted in a statistically significant decrease in the combined prevalence of severe chronic atrophic gastritis, intestinal metaplasia (IM), dysplasia, and gastric cancer, as evaluated in 1999 (odds ration [OR], 0.77) and 2003 (OR 0.60 ), and had favorable effects on the average histopathologic severity and progression/regression of precancerous gastric lesions, as evaluated in 2003 [14]. Fewer subjects receiving $H$. pylori eradication therapy $(1.7 \%)$ than the number receiving placebo $(2.4 \%)$ developed gastric cancer (adjusted $P=0.14$ ) [14]. No statistically significant favorable effects were noted for garlic or vitamin supplementation [14].

In a recent multicenter, open-label, RCT conducted in Japan on 544 patients with early gastric cancer [15] who were either newly diagnosed and scheduled for endoscopic treatment or were under post-resection follow up after endoscopic treatment, the patients were randomly assigned to receive $H$. pylori eradication therapy $(n=272)$ or no eradication $(n=272)$; at the time of the 3-year follow-up examination, metachronous gastric cancer was found to have developed in 9 patients in the eradication group and 24 patients in the control group [15]. In the full intention-to-treat (ITT) population, which included all patients irrespective of the length of follow up, the OR for the development of metachronous gastric cancer was 0.353 ( $95 \%$ confidential interval [CI], 0.161-0.775; $P=0.009$ ); in the modified ITT population, which included patients with at least one post-randomization assessment of the tumor status and adjustment for loss to follow up, the hazard ratio (HR) for the development of metachronous gastric cancer was 0.339 (95\% CI, 0.157-0.729; $P=0.003)$ [15]. Based on the results of this study [15], the Japanese Society for Helicobacter Research (JSHR) revised their 
guideline for physicians on the diagnosis and treatment of $H$. pylori infection in routine medical practice in 2008.

In a Korean study conducted on 1790 subjects [16], gastric cancer was found to occur 10.9 times more frequently in the presence of IM than in its absence, suggesting that for effective prevention of gastric cancer [16], H. pylori eradication therapy must be administered before the development of IM. IM lesions frequently show high expression levels of cyclooxygenase- 2 (COX-2). According to a double-blind, randomized, placebo-controlled trial conducted by Leung et al. [40], on subjects with confirmed IM $(n=213)$ who were randomized to receive either rofecoxib or placebo, there was no evidence to suggest that treatment with rofecoxib for 2 years resulted in the regression of gastric IM [40].

One study focused on the efficacy of $H$. pylori eradication therapy for preventing the development of gastric hyperplastic polyps [17]. Forty-eight patients with hyperplastic gastric polyps infected with $H$. pylori were randomly assigned to an eradication group and a control group which received only the gastroprotective agent, teprenone [17]. While the polyps disappeared by $1-12$ months after the treatment in $69 \%$ of the patients in the eradication group and $H$. pylori infection was eradicated in $86 \%$ of the patients, no change in the polyp or H. pylori status was observed in any of the patients in the control group by 12 months after the start of the study [17].

The efficacy of $H$. pylori eradication against the development of gastric cancer in the remnant stomach after gastrectomy has not been adequately assessed. A total of 138 patients with distal gastric cancer and $H$. pylori infection were randomized to receive $H$. pylori eradication therapy either preoperatively (preop) or postoperatively (postop) [41]. According to ITT analysis, the $H$. pylori eradication rate was $84.6 \%(95 \% \mathrm{CI}$, 73.5-92.4) in the preop group and $83.1 \%$ (95\% CI, 71.791.2) in the postop group $(P=0.99)$, suggesting that the effect of $H$. pylori eradication was not significantly different between the group administered the treatment postoperatively and the group administered the treatment preoperatively [41].

To identify the molecular changes in the gastric mucosa following $H$. pylori eradication, Tsai et al. [42] used cDNA microarrays to analyze 54 gastric biopsies obtained in a randomized, placebo-controlled trial of $H$. pylori therapy. The results of the analysis revealed that, while in the eradication group, 30 genes could be identified whose expression levels had changed significantly from the baseline to 1 year after the treatment [42], 55 genes whose expression levels had changed significantly during the 1-year period (32 up- and 23 downregulated) could be identified in the placebo group [42]. Five 
genes, involved in cell-to-cell adhesion and lining (TACSTD1 and MUC13), cell cycle/differentiation (S100A10), and lipid metabolism and transport (FABP1 and $M T P$ ) were downregulated in the eradication group but upregulated in the placebo group during the same 1 -year period [42].

\section{Nonrandomized cohort studies (Table 2)}

Take et al. [19] reported a prospective cohort study conducted to determine the risk of development of gastric cancer in patients with peptic ulcer diseases; the severity of gastric atrophy was evaluated in this study. Among the 1131 patients followed up for up to 9.5 years, the risk of development of gastric cancer was decreased significantly after $H$. pylori eradication. In addition, the development of gastric cancer was related to the severity of the baseline gastric mucosal atrophy. Analysis with a Cox's proportional hazards model identified persistence of infection (HR, 3.35; 95\% CI, 1.00-11.22) as significant factors for the development of gastric cancer [19].

Takenaka et al. [20] conducted a retrospective cohort study to determine the cancer-preventive effect of $H$. pylori eradication $(n=1807)$ and reported that 6 of $1519(0.39 \%)$ patients in whom H. pylori infection was eradicated and 5 of $288(1.74 \%)$ subjects in whom the infection was persistent developed gastric cancer. Kaplan-Meier analysis also indicated a significantly lower incidence of gastric cancer in the group with eradication of $H$. pylori infection than in the group with persistent infection (OR, 0.20; 95\% CI, 0.061-0.66) [20].

\section{Case-control studies (Table 3)}

Plummer et al. [25] reported, based on the results of examination of gastric biopsy specimens obtained from 2145 participants, that the OR for gastric dysplasia was 15.5 in individuals infected with $\operatorname{cag} A$-positive $H$. pylori as compared with that in uninfected individuals and the OR was 0.90 in individuals infected with $\operatorname{cag} A$ negative $H$. pylori as compared with that in uninfected individuals. Gwack et al. [22] conducted a nested casecontrol study of 100 patients with gastric cancer and 400 control subjects to examine the risk of gastric cancer in relation to the virulence factors of $H$. pylori in a Korean cohort. They showed that CagA seropositivity was significantly associated with a higher risk of gastric cancer among $H$. pylori-infected subjects (OR, 3.57; 95\% CI, 1.05-12.14) [22].

H. pylori infection, atrophic gastritis, and dietary and lifestyle factors were evaluated as risk factors in a large nested case-control study in the European Prospective Investigation into Cancer and Nutrition trial carried out in nine countries (EPIC-EURGAST study), in 233 patients diagnosed as having gastric cancer after enrolment and 910 control subjects [24]. In a conditional logistic regression analysis conducted with adjustment for education, smoking, body weight, and total consumption of vegetables, fruits, and red and preserved meat, $H$. pylori seropositivity was associated with an increased risk of gastric cancer. The OR associated with severe chronic atrophic gastritis was 3.3 (95\% CI, 2.25.2). According to site, the risk of noncardia gastric cancer associated with CagA seropositivity was increased further (OR, 6.5; 95\% CI, 3.3-12.6); on the other hand, severe chronic atrophic gastritis was associated with a tenfold increase in the risk of gastric cancer of the cardia (OR, 11.0; 95\% CI, 3.0-40.9). The causal relationship between infection with $H$. pylori CagA+ strains and gastric cancer in these European populations, even after dietary habits were taken into account, was limited to distal gastric cancer, while a low serum pepsinogen level was strongly associated with gastric cancer of the cardia, thus suggesting a divergent risk pattern for cancer at these two sites [24].

Only a few papers have been published on $H$. pylori infection in gastric cancer patients younger than 40

Table 2. Nonrandomized cohort studies

\begin{tabular}{|c|c|c|c|c|c|c|c|}
\hline Author & Year & $n$ & Subjects & Study arms & Endpoint & Efficacy $(95 \% \mathrm{CI})$ & Period \\
\hline $\begin{array}{l}\text { Takenaka } \\
\text { et al. } \\
\text { [20] }\end{array}$ & 2007 & 1807 & $\begin{array}{l}\text { Patients under } \\
\text { eradication } \\
\text { therapy }\end{array}$ & $\begin{array}{l}\text { Retrospective } \\
\text { cohort } \\
\text { Eradication } 1519 \\
\text { Persistent infection } \\
\quad 288\end{array}$ & $\mathrm{GC}$ & $\begin{array}{l}\text { OR } \\
0.20(0.061-0.66)\end{array}$ & $\begin{array}{l}\text { 39.0 Months } \\
\text { 34.6 Months }\end{array}$ \\
\hline $\begin{array}{l}\text { Ogura et } \\
\text { al. [21] }\end{array}$ & 2008 & 708 & $\begin{array}{l}\text { Patients } \\
\text { diagnosed with } \\
\text { H. pylori } \\
\text { infection }\end{array}$ & $\begin{array}{l}\text { Retrospective } \\
\quad \text { cohort } \\
\text { Eradication } 404 \\
\text { Persistent } 304\end{array}$ & $\mathrm{GC}$ & $\begin{array}{l}\text { HR } \\
0.335(0.114-0.985)\end{array}$ & 3.1 Years \\
\hline $\begin{array}{l}\text { Take et al. } \\
\text { [19] }\end{array}$ & 2007 & 1131 & $\begin{array}{l}\text { Patients with } \\
\text { peptic ulcer }\end{array}$ & $\begin{array}{l}\text { Prospective cohort } \\
\text { Eradication } 953 \\
\text { Persistent infection } \\
\quad 178\end{array}$ & $\mathrm{GC}$ & $\begin{array}{l}\text { HR } \\
\text { Eradication } 1.0 \\
\text { Persistent } 3.9(1.2-12.9) \\
\text { Atrophy } 3.3(1.3-8.6)\end{array}$ & 46.8 Months \\
\hline
\end{tabular}

$n$, number of patients; GC, gastric cancer 
Table 3. Case-control studies

\begin{tabular}{|c|c|c|c|c|c|c|}
\hline Author & Year & Subjects $(n)$ & Risk factor & \multicolumn{2}{|c|}{ OR $(95 \% \mathrm{CI})$} & Period (years) \\
\hline $\begin{array}{l}\text { Gwack et al. } \\
\text { [22] }\end{array}$ & 2006 & $\begin{array}{l}\text { GC } 100 \\
\text { Control } 400\end{array}$ & $\operatorname{CagA}(+)$ vs $(-)$ & \multicolumn{2}{|l|}{$3.74(1.10-12.73)$} & 9 \\
\hline $\begin{array}{l}\text { Hansen et al. } \\
{[23]}\end{array}$ & 2007 & $\begin{array}{l}\text { Cardia GC } 44 \\
\text { Noncardia GC } 129 \\
\text { Control } 3\end{array}$ & $\begin{array}{l}\text { Hp infection } \\
\text { PG(+) }\end{array}$ & \multicolumn{2}{|l|}{$\begin{array}{l}4.75(2.59-8.81) \\
4.47(2.71-7.37)\end{array}$} & 11.9 \\
\hline Palli et al. [24] & 2007 & $\begin{array}{l}\text { GC } 233 \\
\text { - Noncardia GC } 127 \\
\text { - Cardia GC } 54 \\
\text { - Mixed GC } 4 \\
\text { - Undetermined GC } 44 \\
\text { Control } 910\end{array}$ & $\begin{array}{l}\mathrm{Hp} \operatorname{IgG}(+) \text { vs }(-) \\
\mathrm{CagA} \mathrm{Ab}(+) \text { vs }(-) \\
\mathrm{AG}(+) \text { vs }(-)\end{array}$ & \multicolumn{2}{|c|}{$\begin{array}{l}2.6(1.7-3.9) \\
6.5(3.3-12.6) \text { for noncardia GC } \\
0.8(0.4-1.9) \text { for cardia GC } \\
2.4(1.3-4.5) \text { for noncardia GC } \\
11.0(3.0-40.9) \text { for cardia GC }\end{array}$} & 6.1 \\
\hline $\begin{array}{l}\text { Plummer et al. } \\
{[25]}\end{array}$ & 2007 & $\begin{array}{l}\text { All subjects } 2145 \\
\text { Dysplasia } 120 \\
\text { Control } 91\end{array}$ & $\begin{array}{l}\text { CagA (+) vs } \\
\text { uninfected }\end{array}$ & \multicolumn{2}{|l|}{$15.5(6.42-37.2)$} & 3.5 \\
\hline $\begin{array}{l}\text { Masuda et al. } \\
\text { [26] }\end{array}$ & 2007 & $\begin{array}{l}\mathrm{GC}(<40) 31 \\
\text { Control } 120\end{array}$ & Hp infection & \multicolumn{2}{|c|}{$13.69(5.11-36.71)$} & 5 \\
\hline $\begin{array}{l}\text { Sasazuki et al. } \\
\text { [27] }\end{array}$ & 2006 & $\begin{array}{l}\text { GC } 511 \\
\text { Control } 511\end{array}$ & $\begin{array}{l}\text { Hp IgG(-) PG }(-) \\
\text { Hp IgG(-) PG (+) } \\
\text { Hp IgG(+) PG (-) } \\
\text { Hp IgG(+) PG (+) } \\
\text { Hp IgG(+) vs }(-) \\
\text { PG(+) vs (-) }\end{array}$ & \multicolumn{2}{|l|}{$\begin{array}{l}1.0(2.0-12.1) \\
4.9(4.5-14.0) \\
4.2(2.2-8.0) \\
10.1(5.6-18.2) \\
11.4(4.4-29.2) \\
3.2(1.5-7.0)\end{array}$} & 5 \\
\hline $\begin{array}{l}\text { Sawaya et al. } \\
\text { [28] }\end{array}$ & 2008 & $\begin{array}{l}\text { GC } 17 \\
\text { AG } 13\end{array}$ & $\begin{array}{l}\text { P53DINP1 mRNA } \\
\text { expression }\end{array}$ & \multicolumn{2}{|c|}{$\mathrm{GC}<\mathrm{AG}(P<0.05)$} & Not described \\
\hline $\begin{array}{l}\text { Tatemichi } \\
\text { et al. [29] }\end{array}$ & 2008 & $\begin{array}{l}\text { GC } 350 \\
\text { Control } 350\end{array}$ & $\begin{array}{l}\text { Hp IgG negative } \\
\text { Hp IgG low } \\
\text { Hp IgG middle } \\
\text { Hp IgG high }\end{array}$ & $\begin{array}{l}\text { Differentiated } \\
1.0 \\
5.9(3.0-11.6) \\
4.4(2.2-8.5) \\
3.2(1.6-6.4)\end{array}$ & $\begin{array}{l}\text { Undifferentiated } \\
1.0 \\
6.4(2.1-19.6) \\
5.9(1.9-18.5) \\
7.8(2.4-24.9)\end{array}$ & 15 \\
\hline $\begin{array}{l}\text { Watanabe } \\
\text { et al. [30] }\end{array}$ & 2006 & $\begin{array}{l}\text { GC } 53 \\
\mathrm{Hp}(+) \text { NUD } 122\end{array}$ & DQB1*0401 & $2.83(1.44-5.55)$ & & Not described \\
\hline
\end{tabular}

n, number of patients; GC, gastric cancer; AG, atrophic gastritis; PG, pepsinogen; NUD, nonulcer dyspepsia; Hp, H. pylori

years of age. Masuda et al. [26] reported that the prevalence of $H$. pylori infection was higher in patients with gastric cancer than in patients with a normal endoscopic study or those with chronic gastritis, especially among subjects younger than 40 years old (OR, 13.7). Gastric cancer in patients younger than 40 years is closely associated with $H$. pylori infection.

\section{Meta-analysis}

Wang et al. [18] reported the results of a meta-analysis of 87 relevant studies, including 19 case-control studies, conducted to estimate the prevalence of $H$. pylori infection in early gastric cancer. The prevalence of $H$. pylori infection was significantly higher in patients with early gastric cancer than in the noncancer controls (OR, 3.38; 95\% CI, 2.15-5.33). The prevalence of $H$. pylori infection among patients with early gastric cancer was significantly higher than that among patients with advanced gastric cancer (OR, 2.13; 95\% CI, 1.75-2.59) and the prevalence of the infection was 16 -fold higher in patients with differentiated-type early gastric cancer than in those with undifferentiated-type early gastric cancer
(OR, 16.53; 95\% CI, 2.64-103.43). They concluded that the prevalence of $H$. pylori infection was significantly higher in patients with early gastric cancer as compared with that in noncancer controls or patients with advanced gastric cancer, which suggests a causal relationship between $H$. pylori infection and early gastric cancer [18].

\section{Polymorphisms and $\mathrm{H}$. pylori-associated gastric cancer (Table 4)}

The interplay between bacterial factors and host gene polymorphisms may explain why gastric cancer occurs in only a small fraction of $H$. pylori-infected cohorts. Polymorphisms of the interleukin-1 beta gene $(I L-1 B)$ and interleukin-1 receptor antagonist gene (IL-1RN) have been shown to be associated with an increased risk of gastric atrophy and cancer, especially in $H$. pyloriinfected subjects. In an Omani Arab population, while $I L-1 R N$ polymorphism was found to be associated with an increased risk of gastric cancer, consistent with previous reports [43], the $I L-1 B-31$ polymorphism was not associated with increased gastric cancer risk [31], sup- 
Table 4. Genetic polymorphisms associated with the development of gastric cancer

\begin{tabular}{|c|c|c|c|c|c|}
\hline Authors & Year & Country & Patients $(n)$ & $\begin{array}{l}\text { Polymorphism associated with } \\
\text { enhanced risk }\end{array}$ & $\begin{array}{l}\text { Odds ratio } \\
(95 \% \mathrm{CI})\end{array}$ \\
\hline \multirow{3}{*}{$\begin{array}{l}\text { Al-Moundhri } \\
\text { et al. [31] }\end{array}$} & \multirow[t]{3}{*}{2006} & \multirow[t]{3}{*}{ Oman } & GC 118 & IL-1RN -2018*2 & $2.2(1.0-3.3)$ \\
\hline & & & Control 245 & IL-1RN -2018*2 Hp(+) & $3.5(1.0-11.9)$ \\
\hline & & & & IL-1B $-31,-511$, and +3954 & NS \\
\hline \multirow{5}{*}{$\begin{array}{l}\text { García-González } \\
\text { et al. [50] } \\
\text { Hou et al. [33] }\end{array}$} & 2007 & Spain & $\begin{array}{l}\text { GC } 404 \\
\text { Control } 404\end{array}$ & $\begin{array}{l}\text { IL-1B, IL-1RN, IL-12p40, LTA,IL-10, IL-4, } \\
\text { TGF-B1 }\end{array}$ & NS \\
\hline & 2007 & Poland & GC 305 & TNFA $-308 \mathrm{G} / \mathrm{A}$ & $1.4(1.0-2.0)$ \\
\hline & & & Control 427 & TNFA -308 A/A & $2.5(1.3-4.9)$ \\
\hline & & & & IFNGR2 Ex7-128 T/C & $1.5(1.0-2.3)$ \\
\hline & & & & IFNGR2 Ex7-128 C/C & $1.7(1.1-2.7)$ \\
\hline \multirow{2}{*}{$\begin{array}{l}\text { Kubben et al. } \\
\text { [34] }\end{array}$} & \multirow[t]{2}{*}{2006} & \multirow[t]{2}{*}{ Netherlands } & GC 79 & MMP-7 & $0.50(0.28-0.87)$ \\
\hline & & & Control 169 & MMP-2, -8, -9 TIMP-1, -2 & NS \\
\hline $\begin{array}{l}\text { Masuda et al. } \\
{[26]}\end{array}$ & 2007 & Japan & $\begin{array}{l}\mathrm{GC}(<40) 31 \\
(60-70) 231 \\
(80<) 38\end{array}$ & P4502E1 (CYP2E1) & NS \\
\hline \multirow[t]{2}{*}{ Prasad et al. [35] } & \multirow[t]{2}{*}{2008} & \multirow[t]{2}{*}{ India } & GC 62 & PPAR $\gamma$ G carrier & $2.14(1.11-4.10)$ \\
\hline & & & Control 241 & $\operatorname{PPAR} \gamma \mathrm{G}$ carrier $\mathrm{Hp}(+)$ & $3.05(1.20-7.81)$ \\
\hline \multirow[t]{3}{*}{ Seno et al. [36] } & \multirow[t]{3}{*}{2007} & \multirow{3}{*}{ Japan } & GC 100 & IL-4- 984 and 2983 AA/GA & $0.3(0.1-0.9)$ \\
\hline & & & NUD 93 & IL-1RN- 1102 and 6110 CG/GA (>66 years) & $0.2(0.1-0.7)$ \\
\hline & & & & $\begin{array}{l}\text { IL-1alpha, IL-1beta, IL-4R, IL-8, IL-10, } \\
\text { IL-12, TNF-alpha, INF-beta, IFN-gamma }\end{array}$ & NS \\
\hline \multirow[t]{2}{*}{ Shirai et al. [37] } & \multirow[t]{2}{*}{2006} & \multirow[t]{2}{*}{ Japan } & GC 181 & IL-8-251 T/T for $\mathrm{MSH}$ & $5.2(1.5-18.0)$ \\
\hline & & & Control 482 & IL-8-251, IL-1B-511, IL-1RN, TNFA-857 & NS \\
\hline
\end{tabular}

$n$, number of patients; NS, not significant; GC, gastric cancer; NUD, nonulcer dyspepsia; Hp, Helicobacter pylori

porting the notion of ethnic differences in the effect of $I L-1 B$ polymorphism on gastric carcinogenesis. According to a study by Zabaleta et al. [44], the presence of the $I L 1 B+3954 T$ allele was a risk marker for multifocal atrophic gastritis in the population studied. Seno et al. [36] reported, based on a study of 207 single-nucleotide polymorphisms (SNPs), that polymorphisms of the $I L-4$ and $I L-1 R N$ genes were negatively associated with the risk of development of gastric cancer associated with H. pylori infection.

On the other hand, the $I L-8-251 T / T$ genotype was associated with a significantly increased risk of highfrequency microsatellite instability (MSI-H) gastric cancer compared with that of low-frequency MSI (MSIL) or MSI-stable gastric cancers and noncancer controls [37]. The $M P O-463 G / G$ genotype, which is associated with increased myeloperoxidase (MPO) expression and antral IM, has been reported to be a risk factor for gastric cancer arising from the antrum [45].

In relation to the association of gastric cancer with polymorphisms of genes responsible for Th1-cellmediated immune responses, Hou et al. [33] concluded, from a population-based study of 305 gastric cancer cases and 427 age- and sex-matched controls in Poland, that two Th1-related polymorphisms (TNF $\alpha-308 \mathrm{~A}>$ $\mathrm{G}$ and IFN $\gamma \mathrm{R} 2 \mathrm{Ex} 7-128 \mathrm{C}>\mathrm{T}$ ) may be associated with an increased risk of gastric cancer.

Matrix metalloproteinase (MMP)-related SNPs, especially MMP-7(-181A $>$ G) and TIMP-2(303C > T), might be helpful in identifying gastric cancer patients with a poor clinical outcome [34]. The TGFB1 T+869C gene polymorphism was shown to be involved in susceptibility to duodenal ulcer, but not in that to gastric cancer [32]. While 8-hydroxy-2'-deoxyguanosine (8oxo-dG) levels in the gastric mucosa were increased in carriers of $H$. pylori, the levels were significantly higher in a small subset of subjects having a homozygous variant allele of the 8-oxoguanosine-glycosylase 1 (OGG1) gene, which codes for the enzyme removing 8-oxo-dG from DNA [46]. The Pro12Ala PPAR $\gamma$ polymorphism has also been shown to be associated with the development of gastric cancer, and is a potential marker of genetic susceptibility to gastric cancer with $H$. pylori infection [35].

E-Cadherin is an adhesion molecule thought to be involved in the development of gastric cancer. Germline mutations in the E-Cadherin gene $(\mathrm{CDH} 1)$ have been identified in hereditary diffuse gastric cancer, and a promoter polymorphism at position $-160 \mathrm{C} / \mathrm{A}$ of $\mathrm{CDH} 1$ has been shown to influence the risk of gastric cancer in some studies [47, 48]. However, Jenab et al. [49] reported that none of the $C D H 1$ polymorphisms or haplotypes analyzed were associated with gastric cancer risk.

Furthermore, according to a report by GarciaGonzalez et al. [50], at least in some white populations examined in Spain, the contribution of the cytokine gene polymorphisms evaluated $(I L-1 B, I L-1 R N, I L-$ $12 p 40, L T A, I L-10, I L-4$, and $T G F-B 1)$ to gastric cancer susceptibility may be less relevant than previously reported. Furthermore, although gastric cancer in 
patients younger than 40 years of age was shown to be closely associated with $H$. pylori infection, it was not associated with genetic polymorphism of P4502E1 (CYP2E1) [26].

\section{Dietary factors}

Food factors seem to have a very important influence on the risk of development of gastric cancer. According to the EPIC-EURGAST study conducted by Gonzalez et al. [38], while there seemed to be no evidence of any association between fresh fruit intake and gastric cancer risk, a negative association was possible between total vegetable (calibrated HR, 0.66; 95\% CI, 0.35-1.22 per 100-g increase) and onion/garlic intake (calibrated HR, 0.70; 95\% CI, 0.38-1.29 per 10-g increase) and the risk of development of intestinal-type gastric cancer. They also reported that the risk of noncardia gastric cancer was statistically significantly associated with the total intake of meat (calibrated HR per 100-g/day increase, $3.52 ; 95 \%$ CI, 1.96 to 6.34 ), red meat (calibrated HR per 50 -g/day increase, 1.73 ; $95 \%$ CI, 1.03 to 2.88 ), and processed meat (calibrated HR per 50-g/day increase, 2.45; $95 \% \mathrm{CI}, 1.43$ to 4.21 ), and they noted that this association between the risk of noncardia gastric cancer and total meat intake was especially pronounced in $H$. pylori-infected subjects (OR per 100-g/day increase, 5.32; 95\% CI, 2.10 to 13.4 ) [39].

\section{Japanese guideline on the diagnosis and treatment of H. pylori infection}

According to the previous guideline for physicians on the diagnosis and treatment of $H$. pylori infection in routine medical practice published by the Japanese Society for Helicobacter Research (JSHR) [51], $H$. pylori eradication therapy was recommended in patients with low-grade duodenal ulcer. Although eradication therapy was also recommended for patients with lowgrade gastric mucosa-associated lymphoid tissue (MALT) lymphomas, it was suggested that this be undertaken only at specialist institutions. Furthermore, the significance of $H$. pylori eradication therapy after endoscopic mucosal resection or gastrectomy for gastric cancer was still under evaluation, as was that in patients with hyperplastic polyps, chronic atrophic gastritis, or nonulcer dyspepsia. However, according to the recently updated guideline by the JSHR, $H$. pylori eradication is recommended at recommendation level $\mathrm{A}$; i.e., based on strong scientific evidence, for all patients with $H$. pylori infection. A previous nonrandomized study [13] and recent open-label RCT [15] showed that $H$. pylori eradication after endoscopic resection for early gastric cancer could prevent the development of metachronous gastric cancer.

As for the $H$. pylori eradication treatment, triple therapy, consisting of amoxicillin (AMX) and clarithromycin (CLR), along with a proton pump inhibitor (PPI), was officially authorized in the year 2000 as the first-line regimen for $H$. pylori eradication in Japan. Then, in 2007, the combination of metronidazole (MNZ), AMX, and a PPI was approved as a second-line regimen. Although the $H$. pylori eradication rate following firstline treatment was around $90 \%$ in 2000 [52], it has declined in recent years to less than $80 \%$. Such eradication failure has been attributed mainly to the development of antibiotic resistance to CLR [53] (primary resistance rate, 9.1\% [54]; secondary resistance rate, $79.2 \%$ in Japan). Under such circumstances, the regimen for $H$. pylori eradication was switched to the secondline regimen consisting of AMX, MNZ, and a PPI [55, 56]. Even after treatment with the second-line regimen, a large-scale multicenter study in the Tokyo Metropolitan area showed that eradication failure was still observed in approximately $10 \%$ of patients [57], suggesting an increasing demand for the development of third-line regimens.

In 2009, the JSHR has just established a board certification system for doctors treating $H$. pylori infection; the JSHR aims to standardize the diagnostic and therapeutic medical skills required to eradicate this bacterium in Japan.

\section{Summary}

In summary, the association between $H$. pylori and the development of gastric cancer is now more clearly established than before. As announced by the JSHR recently, $H$. pylori eradication should be undertaken in all subjects who are infected, based on all the accumulated scientific evidence. For this purpose, standard effective $H$. pylori eradication protocols, including third-line regimens, should be urgently developed. Rokkas et al. [58] reported that, by adopting the firstand second-line regimens proposed by the Maastricht III consensus and a levofloxacin (LEV)-based regimen as the third-line regimen, high cumulative eradication rates, of $89.6 \%$ (ITT) and $98.1 \%$ (per protocol; PP), were achieved. Quinolones are one of the most suitable candidate categories for a third-line regimen $[58,59]$, even though a high resistance rate to gatifloxacin $(43 \%)$ was reported in $H$. pylori isolated from patients with first- and/or second-line eradication failure [53]. Recently, a new generation of quinolones (e.g., sitafloxacin and garenoxacin) has been developed; in-vitro, these have been shown to overcome the resistance of $H$. pylori strains that have resistance-determining gyr $A$ 
mutations, and these quinolones are expected to be tested clinically [60]. Another possible candidate component for a third-line eradication regimen is rifabutin [61], which has very low resistance rates at present in Japan, although there remains the problem of crossresistance to rifampicin [62]. The efficacy of the abovementioned candidate agents should be carefully evaluated in well-designed clinical trials.

In conclusion, we emphasize that, even after eradication of $H$. pylori has been achieved in patients with high-risk gastric mucosa (frequently seen in older subjects with severe gastric atrophy), endoscopic surveillance for gastric cancer should not be omitted in such high risk patients.

Acknowledgments This study was supported by a Grant-in-Aid for Exploratory Research from the Japan Society for the Promotion of Science (JSPS; No. 19659057 to H.S.) and a grant from the Keio Gijuku Academic Development Funds (to H.S.).

\section{References}

1. Suzuki H, Hibi T, Marshall BJ. Helicobacter pylori: present status and future prospects in Japan. J Gastroenterol 2007;42: $1-15$.

2. Warren JR, Marshall BJ. Unidentified curved bacilli on gastric epithelium in active chronic gastritis. Lancet 1983;I:1273-5.

3. Suzuki H, Nishizawa T, Masaoka T, Mori M, Iwasaki E, Tsuchimoto K, et al. Helicobacter pylori infection and gastric cancer. JMAJ 2005;48:497-504.

4. IARC. Working Group on the Evaluation of Carcinogenic Risks to Humans. Helicobacter pylori. In: Schistosomes, liver flukes and Helicobacter pylori views and expert opinions of an IARC Working Group On The Evaluation of Carcinogenic Risks To Humans. Lyon: IARC 1994. p. 177-240.

5. Forman D, Newell DG, Fullerton F, Yarnell JW, Stacey AR, Wald N, et al. Association between infection with Helicobacter pylori and risk of gastric cancer: evidence from a prospective investigation. BMJ 1991;302:1302-5.

6. Nomura A, Stemmermann GN, Chyou PH, Kato I, Perez-Perez GI, Blaser MJ. Helicobacter pylori infection and gastric carcinoma among Japanese Americans in Hawaii. N Engl J Med 1991;325:1132-6.

7. Parsonnet J, Friedman GD, Vandersteen DP, Chang Y, Vogelman JH, Orentreich N, et al. Helicobacter pylori infection and the risk of gastric carcinoma. N Engl J Med 1991;325:1127-31.

8. Uemura N, Okamoto S, Yamamoto S, Yamaguchi S, Mashiba H, Taniyama K, et al. Helicobacter pylori infection and the development of gastric cancer. N Engl J Med 2001;345:784-9.

9. Yamagata H, Kiyohara Y, Aoyagi K, Kato I, Iwamoto $H$, Nakayama K, et al. Impact of Helicobacter pylori infection on gastric cancer incidence in a general Japanese population: the Hisayama study. Arch Intern Med 2000;160:1962-8.

10. Wong BC, Lam SK, Wong WM, Chen JS, Zheng TT, Feng RE, et al. Helicobacter pylori eradication to prevent gastric cancer in a high-risk region of China: a randomized controlled trial. JAMA 2004;291:187-94.

11. Take S, Mizuno M, Ishiki K, Nagahara Y, Yoshida T, Yokota K, et al. The effect of eradicating Helicobacter pylori on the development of gastric cancer in patients with peptic ulcer disease. Am J Gastroenterol 2005;100:1037-42.
12. Huang JQ, Zheng GF, Sumanac K, Irvine EJ, Hunt RH. Metaanalysis of the relationship between cagA seropositivity and gastric cancer. Gastroenterology 2003;125:1636-44.

13. Uemura N, Mukai T, Okamoto S, Yamaguchi S, Mashiba H, Taniyama K, et al. Effect of Helicobacter pylori eradication on subsequent development of cancer after endoscopic resection of early gastric cancer. Cancer Epidemiol Biomarkers Prev 1997; 6:639-42.

14. You WC, Brown LM, Zhang L, Li JY, Jin ML, Chang YS, et al. Randomized double-blind factorial trial of three treatments to reduce the prevalence of precancerous gastric lesions. J Natl Cancer Inst 2006;98:974-83.

15. Fukase K, Kato M, Kikuchi S, Inoue K, Uemura N, Okamoto S, et al. Effect of eradication of Helicobacter pylori on incidence of metachronous gastric carcinoma after endoscopic resection of early gastric cancer: an open-label, randomised controlled trial. Lancet 2008;372:392-7.

16. Kim N, Park RY, Cho SI, Lim SH, Lee KH, Lee W, et al. Helicobacter pylori infection and development of gastric cancer in Korea: long-term follow-up. J Clin Gastroenterol 2008;42:448-54.

17. Ji F, Wang ZW, Ning JW, Wang QY, Chen JY, Li YM. Effect of drug treatment on hyperplastic gastric polyps infected with Helicobacter pylori: a randomized, controlled trial. World J Gastroenterol 2006;12:1770-3.

18. Wang C, Yuan Y, Hunt RH. The association between Helicobacter pylori infection and early gastric cancer: a meta-analysis. Am J Gastroenterol 2007;102:1789-98.

19. Take S, Mizuno M, Ishiki K, Nagahara Y, Yoshida T, Yokota K, et al. Baseline gastric mucosal atrophy is a risk factor associated with the development of gastric cancer after Helicobacter pylori eradication therapy in patients with peptic ulcer diseases. J Gastroenterol 2007;42 (Suppl 17):21-7.

20. Takenaka R, Okada H, Kato J, Makidono C, Hori S, Kawahara $\mathrm{Y}$, et al. Helicobacter pylori eradication reduced the incidence of gastric cancer, especially of the intestinal type. Aliment Pharmacol Ther 2007:25:805-12.

21. Ogura K, Hirata Y, Yanai A, Shibata W, Ohmae T, Mitsuno Y, et al. The effect of Helicobacter pylori eradication on reducing the incidence of gastric cancer. J Clin Gastroenterol 2008;42:279-83.

22. Gwack J, Shin A, Kim CS, Ko KP, Kim Y, Jun JK, et al. CagAproducing Helicobacter pylori and increased risk of gastric cancer: a nested case-control study in Korea. Br J Cancer 2006;95: 639-41.

23. Hansen S, Vollset SE, Derakhshan MH, Fyfe V, Melby KK, Aase $\mathrm{S}$, et al. Two distinct aetiologies of cardia cancer; evidence from premorbid serological markers of gastric atrophy and Helicobacter pylori status. Gut 2007;56:918-25.

24. Palli D, Masala G, Del Giudice G, Plebani M, Basso D, Berti D, et al. CagA+Helicobacter pylori infection and gastric cancer risk in the EPIC-EURGAST study. Int J Cancer 2007;120:859-67.

25. Plummer M, van Doorn LJ, Franceschi S, Kleter B, Canzian F, Vivas J, et al. Helicobacter pylori cytotoxin-associated genotype and gastric precancerous lesions. J Natl Cancer Inst 2007; 99:1328-34.

26. Masuda G, Tokunaga A, Shirakawa T, Togashi A, Kiyama T, Kato S, et al. Helicobacter pylori infection, but not genetic polymorphism of CYP2E1, is highly prevalent in gastric cancer patients younger than 40 years. Gastric Cancer 2007;10:98-103.

27. Sasazuki S, Inoue M, Iwasaki M, Otani T, Yamamoto S, Ikeda S, et al. Effect of Helicobacter pylori infection combined with CagA and pepsinogen status on gastric cancer development among Japanese men and women: a nested case-control study. Cancer Epidemiol Biomarkers Prev 2006;15:1341-7.

28. Sawaya M, Yoshimura T, Shimoyama T, Munakata A, Fukuda S. Difference of p53AIP1 mRNA expression in gastric mucosa between patients with gastric cancer and chronic gastritis infected with Helicobacter pylori. J Clin Gastroenterol 2008;42:351-5.

29. Tatemichi M, Sasazuki S, Inoue M, Tsugane S. Different etiological role of Helicobacter pylori (Hp) infection in carcinogenesis 
between differentiated and undifferentiated gastric cancers: a nested case-control study using $\operatorname{IgG}$ titer against Hp surface antigen. Acta Oncol 2008;47:360-5.

30. Watanabe Y, Aoyama N, Sakai T, Shirasaka D, Maekawa S, Kuroda K, et al. HLA-DQB1 locus and gastric cancer in Helicobacter pylori infection. J Gastroenterol Hepatol 2006;21:420-4.

31. Al-Moundhri MS, Al-Nabhani M, Al-Bahrani B, Burney IA, AlMadhani A, Ganguly SS, et al. Interleukin-1 beta gene (IL-1B) and interleukin 1 receptor antagonist gene (IL-1RN) polymorphisms and gastric cancer risk in an Omani Arab population. Gastric Cancer 2006;9:284-90.

32. Garcia-Gonzalez MA, Strunk M, Piazuelo E, Benito R, Santolaria S, Jimenez P, et al. TGFB1 gene polymorphisms: their relevance in the susceptibility to Helicobacter pylori-related diseases. Genes Immun 2006;7:640-6.

33. Hou L, El-Omar EM, Chen J, Grillo P, Rabkin CS, Baccarelli A, et al. Polymorphisms in Th1-type cell-mediated response genes and risk of gastric cancer. Carcinogenesis 2007;28:118-23.

34. Kubben FJ, Sier CF, Meijer MJ, van den Berg M, van der Reijden JJ, Griffioen G, et al. Clinical impact of MMP and TIMP gene polymorphisms in gastric cancer. Br J Cancer 2006;95:744-51.

35. Prasad KN, Saxena A, Ghoshal UC, Bhagat MR, Krishnani N. Analysis of Pro12Ala PPAR gamma polymorphism and Helicobacter pylori infection in gastric adenocarcinoma and peptic ulcer disease. Ann Oncol 2008;19:1299-303.

36. Seno H, Satoh K, Tsuji S, Shiratsuchi T, Harada Y, Hamajima N, et al. Novel interleukin-4 and interleukin-1 receptor antagonist gene variations associated with non-cardia gastric cancer in Japan: comprehensive analysis of 207 polymorphisms of 11 cytokine genes. J Gastroenterol Hepatol 2007;22:729-37.

37. Shirai K, Ohmiya N, Taguchi A, Mabuchi N, Yatsuya H, Itoh A, et al. Interleukin-8 gene polymorphism associated with susceptibility to non-cardia gastric carcinoma with microsatellite instability. J Gastroenterol Hepatol 2006;21:1129-35.

38. Gonzalez CA, Pera G, Agudo A, Bueno-de-Mesquita HB, Ceroti $\mathrm{M}$, Boeing $\mathrm{H}$, et al. Fruit and vegetable intake and the risk of stomach and oesophagus adenocarcinoma in the European Prospective Investigation into Cancer and Nutrition (EPICEURGAST). Int J Cancer 2006;118:2559-66.

39. Gonzalez CA, Jakszyn P, Pera G, Agudo A, Bingham S, Palli D, et al. Meat intake and risk of stomach and esophageal adenocarcinoma within the European Prospective Investigation Into Cancer and Nutrition (EPIC). J Natl Cancer Inst 2006;98:345-54.

40. Leung WK, Ng EK, Chan FK, Chan WY, Chan KF, Auyeung AC, et al. Effects of long-term rofecoxib on gastric intestinal metaplasia: results of a randomized controlled trial. Clin Cancer Res 2006;12:4766-72.

41. Kim CG, Song HJ, Kook MC, Hong EK, Park S, Lee JY, et al. Preoperative versus postoperative Helicobacter pylori eradication therapy in gastric cancer patients: a randomized trial. Am J Gastroenterol 2008;103:48-54.

42. Tsai CJ, Herrera-Goepfert R, Tibshirani RJ, Yang S, Mohar A, Guarner J, et al. Changes of gene expression in gastric preneoplasia following Helicobacter pylori eradication therapy. Cancer Epidemiol Biomarkers Prev 2006;15:272-80.

43. El-Omar EM, Carrington M, Chow WH, McColl KE, Bream JH, Young HA, et al. Interleukin-1 polymorphisms associated with increased risk of gastric cancer. Nature 2000;404:398-402.

44. Zabaleta J, Camargo MC, Piazuelo MB, Fontham E, Schneider BG, Sicinschi LA, et al. Association of interleukin-1beta gene polymorphisms with precancerous gastric lesions in African Americans and Caucasians. Am J Gastroenterol 2006;101:163-71.

45. Steenport M, Eom H, Uezu M, Schneller J, Gupta R, Mustafa Y, et al. Association of polymorphisms in myeloperoxidase and catalase genes with precancerous changes in the gastric mucosa of patients at inner-city hospitals in New York. Oncol Rep 2007;18: 235-40.

46. Izzotti A, De Flora S, Cartiglia C, Are BM, Longobardi M, Camoirano A, et al. Interplay between Helicobacter pylori and host gene polymorphisms in inducing oxidative DNA damage in the gastric mucosa. Carcinogenesis 2007;28:892-8.

47. Humar B, Graziano F, Cascinu S, Catalano V, Ruzzo AM, Magnani M, et al. Association of CDH1 haplotypes with susceptibility to sporadic diffuse gastric cancer. Oncogene 2002;21: 8192-5.

48. Medina-Franco H, Ramos-De la Medina A, Vizcaino G, MedinaFranco JL. Single nucleotide polymorphisms in the promoter region of the E-cadherin gene in gastric cancer: case-control study in a young Mexican population. Ann Surg Oncol 2007;14: 2246-9.

49. Jenab M, McKay JD, Ferrari P, Biessy C, Laing S, Munar GM, et al. CDH1 gene polymorphisms, smoking, Helicobacter pylori infection and the risk of gastric cancer in the European Prospective Investigation into Cancer and Nutrition (EPIC-EURGAST). Eur J Cancer 2008;44:774-80.

50. Garcia-Gonzalez MA, Lanas A, Quintero E, Nicolas D, Parra-Blanco A, Strunk M, et al. Gastric cancer susceptibility is not linked to pro-and anti-inflammatory cytokine gene polymorphisms in whites: a Nationwide Multicenter Study in Spain. Am J Gastroenterol 2007;102:1878-92.

51. Asaka M, Satoh K, Sugano K, Sugiyama T, Takahashi S, Fukuda $\mathrm{Y}$, et al. Guidelines in the management of Helicobacter pylori infection in Japan. Helicobacter 2001;6:177-86.

52. Lind T, Veldhuyzen van Zanten S, Unge P, Spiller R, Bayerdorffer E, O'Morain C, et al. Eradication of Helicobacter pylori using 1-week triple therapies combining omeprazole with two antimicrobials: the MACH I Study. Helicobacter 1996;1:138-44.

53. Nishizawa T, Suzuki H, Kurabayashi K, Masaoka T, Muraoka H, Mori M, et al. Gatifloxacin resistance and mutations in gyrA after unsuccessful Helicobacter pylori eradication in Japan. Antimicrob Agents Chemother 2006;50:1538-40.

54. Miyaji H, Azuma T, Ito S, Suto H, Ito Y, Yamazaki Y, et al. Susceptibility of Helicobacter pylori isolates to metronidazole, clarithromycin and amoxycillin in vitro and in clinical treatment in Japan. Aliment Pharmacol Ther 1997;11:1131-6.

55. Nishizawa T, Suzuki H, Masaoka T, Iwasaki E, Hibi T. A new eradication resistance index as a predictor of metronidazolecontaining second-line treatment of Helicobacter pylori. Digestion 2007;76:215-20.

56. Masaoka T, Suzuki H, Kurabayashi K, Nomoto Y, Nishizawa T, Mori M, et al. Could frameshift mutations in the frxA and $r d x A$ genes of Helicobacter pylori be a marker for metronidazole resistance? Aliment Pharmacol Ther 2006;24(Suppl. 4):81-7.

57. Matsuhisa T, Kawai T, Masaoka T, Suzuki H, Ito M, Kawamura $\mathrm{Y}$, et al. Efficacy of metronidazole as second-line drug for the treatment of Helicobacter pylori infection in the Japanese population: a multicenter study in the Tokyo metropolitan area. Helicobacter 2006;11:152-8.

58. Rokkas T, Sechopoulos P, Robotis I, Margantinis G, Pistiolas D. Cumulative $H$. pylori eradication rates in clinical practice by adopting first and second-line regimens proposed by the Maastricht III Consensus and a third-line empirical regimen. Am J Gastroenterol 2009;104:21-5.

59. Nishizawa T, Suzuki H, Hibi T. Quinolone-based third-line therapy for Helicobacter pylori eradication. J Clin Biochem Nutri 2009;44:119-24.

60. Suzuki H, Nishizawa T, Muraoka H, Hibi T. Sitafloxacin and garenoxacin may overcome the antibiotic resistance of Helicobacter pylori with gyrA mutation. Antimicrob Agents Chemother 2009;53:1720-1.

61. Gonzalez Carro P, Perez Roldan F, De Pedro Esteban A, Legaz Huidobro ML, Soto Fernandez S, Roncero Garcia Escribano O, et al. Efficacy of rifabutin-based triple therapy in Helicobacter pylori infected patients after two standard treatments. J Gastroenterol Hepatol 2007;22:60-3.

62. Suzuki S, Suzuki H, Nishizawa T, Kaneko F, Ootani S, Muraoka $\mathrm{H}$, et al. Past rifampicin dosing determines rifabutin resistance of Helicobacter pylori. Digestion 2009;79:1-4. 